\title{
The Evolving Roles of Chinese Visiting Scholars and Students in Sino-US Relations: 1978-2018*
}

\author{
Wang Ji-nan \\ Shanghai International Studies University, Shanghai, China
}

\begin{abstract}
Chinese visting scholars and students are the barometer of Sino-US political relations in the past four decades. This paper divides the People's Republic of China's relations with the US into three phases of the "honey moon" (1978-1988), the "cautious engagement” (1989-2012), and the "strategic competition” (2013 to present). The research shows that during the first stage, Chinese visiting scholars and students were welcomed, because they were perceived as useful tools for the US to engage Beijing in order to promote liberatlization of Chinese politics. After the 1989 Tiananmen Square incident, US still embraced the Chinese visiting scholars and students, albeit in a cautious manner. Since Xi Jin-ping took Presidency, the US has targeted China as a strategic competitor and Chinese visiting scholars and students are imagined as the extension of China's "sharp power”. Thus, the Chinese visiting scholars and students will be faced with more censorship and supervision under the Trump administration in the foreseeable future.
\end{abstract}

Keywords: Chinese visiting scholars and students, Sino-US relations, sharp power, cultural diplomacy, educational exchanges

\section{Introduction}

As early as 1872, the Qing Empire sent 120 young children to study in the United States, thus, opening the pioneer of sending scholars and students to study abroad in modern China. Since the founding of the People's Republic of China in 1949, Sino-US relations have been complex with various of hurdles. Such troublesome political relations have exerted a far-reaching effect on the bilateral exchanges of visiting scholars and students. The two sides have made use of their respective visa policies, scholarships, censorships, and supervisions to influence the target countries' visiting scholars and students. In the three decades, since the founding of the People's Republic of China, however, the educational exchanges between the two giants were almost suspended, let alone exchange of visiting scholars and students. This paper touches down upon Chinese visiting scholars and students from 1978 to 2018, which can roughly be divided into three stages.

\section{Sino-US “Honey Moon” and the Flooding of Chinese Visiting Scholars and Students to America, 1978-1988}

Ever since US President Nixon's historical visit to China in 1972, the door of Sino-US relations was opened. Particularly, after the death of Chairman Mao Ze-dong, China and the US were confronted with a

\footnotetext{
* Acknowledgement: This research is funded by China Scholarship Council and Shanghai International Studies University. Wang Ji-nan, Dr., lecturer, Overseas Training Center, Shanghai International Studies University. A visiting scholar, Cambridge University (2010-2011), UK and currently a visiting scholar, College of New Jersey (2018-2019), the US.
} 
common enemy of the aggressive and assertive Soviet Union. Thus, Beijing and Washington began to transform their bilateral relations from strategic adversaries to "de facto allies" vis-à-vis Moscow. In 1978, Deng Xiao-ping, the noted Chinese politician with a strategic insight, made an important speech on expanding the scales of the overseas visiting program at the work report conference held by the Ministry of Education. At the end of the same year, the Ministry of Education implemented Deng's instructions immediately by sending a total of 52 Chinese visiting scholars to the United States (Mo, Xia, \& Aaron, 2015, p. 291).

On June 23, 1978, on the eve of the Third Plenary Session of the Eleventh Central Committee of the Communist Party of China, Liu Da, then President and Secretary of the Party Committee of Tsinghua University, made a "Report on the Work of Tsinghua University" to Deng Xiao-ping. It was at this meeting that Deng Xiao-ping put forward a view saying that "I am in favor of increasing the number of foreign students and mainly engaging in natural sciences”. Thousands of factions should be sent, not just 10 or eight. This is one of the important ways to achieve a prompt accomplishment and improve the level of science and education of China within five years. During the Cultural Revolution, the work of sending overseas students had been interrupted for many years, so the resumption of sending overseas students is another major event in China's educational circles after the resumption of the college entrance examination in 1979 (Niu, 2019).

In late 1970s and early 1980s, the Americans who visited China were mostly young students in their twenties, studying Chinese history, art, politics, etc.; the Chinese visiting scholars in America were senior professionals, specializing in practical technical subjects, such as polymer chemistry and oil extraction technology, badly needed for China's reform and opening-up. Chinese visiting scholars and students stood better chance of being allowed to visit the US laboratories and campuses where no Soviet visitor was allowed, due to the long-standing US-Soviet game of denying each other's scientists permission to travel to specific places on a tit-for-tat individual basis ${ }^{1}$.

As of 1984 when US President Reagan paid a visit to China, the US received roughly 10,000 Chinese under the educational exchange programs, about two-thirds being students and the rest visiting scholars. The first group of students were concentrated heavily in the basic science. Subsequently, a greater interest in the applied sciences and engineering became evident. Thereafter, more students had pursued studies in economics, finance, management, and social sciences (Jogn, 1984). These skills are needed to deal with practical problems facing China's reform and opening-up.

In the early post-normalization years with the US, the majority of Chinese students were indeed sent to Europe and Japan, but in just three years, the balance shifted, so that by 1983, most were going to the United States. Since this country was the primary choice of Chinese students, the downturn in the proportion (not in absolute numbers) coming to the United States in the last three years may also seem somewhat surprising. According to statistics obtained from the Chinese Embassy in November 1986, there were 4,987 scholars (46\%), 5,716 graduate students (53\%), and 116 undergraduate students (1\%) in the United States, for a total of 10,819 scholars and students with J-1 visas (National Academy of Sciences, 1988, p. 81).

From 1979 to 1987, the figures show an annual increase in the number of Chinese J-1 visas, but a considerable fluctuation in the case of F-1 visas, which were subject to more policy, shifts (National Academy of Sciences, 1988, p. 88).

\footnotetext{
${ }^{1}$ Normalization brings first exchange of U.S. and mainland Chinese scholars (1979). Science, 203(4379), 420.
} 
Table 1

Number of Visas Issued to People's Republic of China Students and Scholars, 1979-1987

\begin{tabular}{lcccl}
\hline Year & J-1 Visas & F-1 Visas & Total & $\begin{array}{l}\text { Percentage of students sent to US } \\
(\%)\end{array}$ \\
\hline 1979 & 807 & 523 & 1,330 & N/A \\
1980 & 1,986 & 2,338 & 4,324 & 17 \\
1981 & 3,066 & 2,341 & 5,407 & 23 \\
1982 & 3,327 & 1,153 & 4,480 & 41 \\
1983 & 3,328 & 1,003 & 4,331 & 60 \\
1984 & 4,420 & 1,677 & 6,097 & 58 \\
1985 & 6,912 & 3,001 & 9,913 & 51 \\
1986 & 7,673 & 5,038 & 12,711 & 48 \\
1987 (fiscal) & 8,179 & 5,235 & 13,414 & N/A \\
Total & 39,698 & 22,309 & 62,007 & N/A \\
\hline
\end{tabular}

Source: 1979-1986: Consular reports, U.S. Department of State. 1987: Visa Office, U.S. Department of State, Washington, DC; Achievement of Education in China, 1980-1985, State Education Commission, Beijing, 1986, p. 50. See National Academy of Sciences, Chinese Students in America: Policies, Issues, and Numbers, Washington, DC: The National Academies Press, 1988, p. 80; \& p. 88.

As shown in Table 1, from 1978 to 1988, Sino-US relations were at a congenial stage, and China was regarded as the important "ally" to check the Soviet expansion in Vietnam and Afghanistan. Thus, Chinese visiting scholars and students were warmly received in the US universities, institutes, and labs.

\section{Sino-US “Cautious Engagement” and the Steady Growth of Chinese Visiting Scholars and Students in the US, 1989-2012}

The "Tiananmen Square” incident in June 4, 1989 was a shock to both Beijing and Washington. After one decade of reform and opening-up, however, the US felt disillusioned that Washington's engagement failed to transform China into a "western-styled democracy". After 1989, the United States passed the Chinese Student Protection Act 1992, which enabled 25,412 Chinese students and exchange scholars (holding F-1 and J-1 visas) to obtain green cards and stay in the United States. China criticized that this was a wrong policy of the United States to interfere in China's internal affairs. The US policy not only brought Sino-US relations to a political distrust, but also seriously affected the development of education exchanges. For example, the number of the Fulbright scholars dropped sharply in 1990 (Yue, 1988, p. 103).

During Clinton administration from 1992 to 2000, Sino-US tension began to relax, and the US gradually lifted its sanction against China. US President Clinton and Chinese President Jiang Ze-ming unanimously agreed that China and US should build a "strategic partnership towards the 21st century". Within this background, Sino-US educational exchanges resumed from the shadow of the "Tiananmen Square" incident. The China Scholarship Council (CSC) was established in 1996 to administrate the State Sponsored Study Abroad Programs (SSSAP). As a non-profit institution, CSC managed and provided financial resources to visiting scholars. According to CSC, the number of CSC-sponsored Chinese scholars increased from 2,044 of 1996 to 13,038 in 2010 (Mo, Xia, \& Aaron, 2015, p. 290), and about 50\% of Chinese visiting scholars and students were studying in the US during that period. Meanwhile, China-US disputes over human rights, Tibet and Taiwan affected the bilateral educational exchanges, and there were cases that Chinese visiting scholars and students were involved in "commercial espionage" in 1990s.

After the September 11, 2011 incident, the US authorities, out of concern for domestic public security, 
promulgated a series of restrictive laws, including the policy of visas, increasing restrictions on sensitive majors, tracking and monitoring foreign students and exchange scholars in the United States. According to the Open Door Yearly Report issued by the American Association for International Education, the growth rate of Chinese students studying in the United States slowed down during the 2001/2002 academic year, and even showed negative growth in the 2003/2004 academic year (Yue, 1988, p. 104). That being said, the Chinese government still gave top priority to the United States in its foreign policy, and both President Jiang and his successor Hu Jin-tao attached great importance to Sino-US educational relations and technological exchanges. Therefore, Chinese visiting scholars and students continued to flood into the US despite sporadic Beijing-Washington political entanglements.

In the first decade of the 21st century, the US remained the primary destination for Chinese visiting scholars and students. In 2009, the US universities and institutes hosted 98,235 students, making up 14.6\% of the total number of international students in the country. Chinese visiting students and scholars relied less on the US fellowship or assistantship, but on Chinese government funding, their home universities' financial

support or their family assistance. The Chinese visiting students had broader majors than that of 1980s, such as life sciences (31\%), engineering (26\%), physical sciences (22\%), social sciences (8\%), humanities (3\%), education (2\%), and other fields (8\%) (Ding \& Li, 2012, pp. 581-582).

As of 2011, the top 10 US universities and institutes hosting Chinese visiting scholars were: University of Michigan, Ann Arbor (139); University of Pittsburgh, Pittsburgh (133); University of Missouri, Kansas City (131); University of California, Los Angeles (129); Cornell University (127); Purdue University, West Lafayette (124); Ohio State University, Columbus (122); Vanderbilt University (120); Yale University (119); and University of Florida (111). In comparison, the top 10 universities and institutes hosting Chinese students were: University of Michigan, Ann Arbor (59); University of Illinois, Urbana-Champaign (51); University of California, Los Angeles (49); Pennsylvania State University, University Park (43); Harvard University (42); University of Maryland, College Park (41); Columbia University in the City of New York (38); University of Southern California (37); University of Wisconsin, Madison (36); and Georgia Institute of Technology(32) (Ding \& Li, 2012, pp. 583-584). The United States remained the first destination for Chinese students for many years. From the resumption of Sino-US educational ties in 1978 to late 2013, there had been more than 1.46 million Chinese students studying in the United States in total, accounting for $47.9 \%$ of the overall number of Chinese students studying abroad in the same period (Yue, 1988, p. 105).

\section{Sino-US “Strategic Competition" and the Predicaments of Chinese Visiting Scholars and Students in the US, 2013 to Today}

Since 2013, when Xi Jin-ping took presidency, China became the second largest economy of the world. Beijing put forward a very ambitious "Belt and Road" initiate, established Asia Infrastructure Investment Bank (AIIB), reactivated Conference on Interaction and Confidence-Building Measures in Asia (CICA), upgraded BRICS, and promoted G20. Within the rhetoric of "China Dream" and "National Rejuvenation”, China began to further expand its educational and cultural exchanges with the rest of the world.

Between 2010 and 2014, more than 100,000 American students studied in China, fulfilling President Obama's goal of "increasing the number of young Americans studying Chinese language and culture" through the "Top 100,000 Program”. In the United States, one out of every three foreign students come from China during this period. The United States also has the largest number of Confucius Institutes (100) and Confucius Classrooms (356) in 
the world, with 200,000 registered students, the harbors of Chinese visiting scholars and students (Li, 2017).

On October 21, 2013, Chinese President Xi Jin-ping pointed out at the 100th Anniversary of the Overseas-Educated Scholars Association of China (WRSA) that, by the end of 2012, the number of Chinese students studying abroad had reached 2.64 million and the number of returnees had reached 1.09 million. Chinese government hoped that a vast number of overseas students would give full play to their advantages, strengthen their domestic and overseas networks, and act as civil ambassadors to promote friendly exchanges between China and the host countries. They were also encouraged to make great efforts to disseminate Chinese voices, and enhance the world better understand and support China (Xi, 2013). In May 2015, Chinese President Xi Jin-ping emphasized at the Central United Front Work Conference once again that overseas students were the new focus of the United Front work. He called for continuous adherence to the guidelines of "supporting overseas students, encouraging them to return home, coming and going freely, and playing their positive roles" (Center on Religion and Chinese Society Purdue University, 2018). A total of 5.3 million people visited China and the United States in 2016, an increase of one million from 2014, which laid a solid foundation for the bilateral educational and cultural exchanges.

However, the US has grave concern that the US engagement of China by inviting Chinese visiting scholars and students would not only fail to bring a democratic China, but also may breed China's cyber populism, anti-Americanism, and ultra-nationalism. Washington even claimed that China's rapid rise and diplomatic assertiveness has challenged the US-led and the Western-dominated world order; Chinese visiting scholars and students fail to help bring China into the Western orbit through dissemination of "universal values".

The US universities and research institutes are continuing to welcome Chinese scholars and students. In 2016/2017, 45,089 Chinese scholars and students visited the US, an increase of 1.3\%, ranking the first among international scholars and students in the US (see Table 2). Take Purdue University as one example, this national university enrolled about 40,000 students in Fall 2017, among whom 3,696 were from the mainland China, about $61 \%$ being undergraduates and 39\% being graduate students. This university also had 484 visiting scholars from China as of Spring 2018 (Center on Religion and Chinese Society Purdue University, 2018).

Table 2

Top 25 Places of Origin of International Scholars, 2015/2016 \& 2016/2017

\begin{tabular}{|c|c|c|c|c|c|}
\hline \multirow{2}{*}{ Rank } & Place of Origin & 2015/2016 & 2016/2017 & Percent of total (\%) & $\begin{array}{l}\text { Percent of change } \\
(\%)\end{array}$ \\
\hline & World total & 134,014 & 134,379 & 100.0 & 0.3 \\
\hline 1 & China & 44,490 & 45,089 & 33.6 & 1.3 \\
\hline 2 & India & 12,379 & 12,447 & 9.3 & 0.5 \\
\hline 3 & South Korea & 7,395 & 7,289 & 5.4 & -1.4 \\
\hline 4 & Germany & 5,345 & 5,352 & 4.0 & 0.1 \\
\hline 5 & Canada & 4,976 & 5,018 & 3.7 & 0.8 \\
\hline 6 & France & 4,545 & 4,457 & 3.3 & -1.9 \\
\hline 7 & Japan & 4,478 & 4,361 & 3.2 & -2.6 \\
\hline 8 & Italy & 4,036 & 4,121 & 3.1 & 2.1 \\
\hline 9 & Brazil & 4,345 & 3,939 & 2.9 & -9.3 \\
\hline 10 & Spain & 3,112 & 3,135 & 2.3 & 0.7 \\
\hline
\end{tabular}

Note. Open Doors, International Scholars of Origin. Retrieved from https://www.iie.org/Research-and-Insights/Open-Doors.

Since Trump took presidency, Sino-US relation has been overshadowed with suspicion and rivalries. 
Chinese President Xi Jin-ping and US President Trump were cautious in case the two giants might fall into a "Thucydides Trap". Thus, the two heads of states jointly decided to establish three dialogue mechanisms during their meeting in April 2017 to avoid a "New Cold War". Then, Chinese vice Premier Liu Yan-dong and US Secretary of State Rex Tillerson co-chaired the first round of Sino-US cultural dialogue in Washington on September 28, 2017. Both sides agreed that (Xinhua Net, 2017):

China and the United States will also promote two-way overseas study and enhance bilateral exchanges among educational institutions and scholars. They will adopt a "double 100,000” two-way overseas study plan, which will allow China to send 100,000 government-sponsored people to study in the United States and permit 100,000 US students to study in China in the next four years. Besides, China will provide 10,000 scholarships in the coming four years to encourage excellent US students to study in China on a short-term basis. The United States will continue to implement the Fulbright scholarship program, a US flagship academic exchange program.

In recent years, China continued to maintain the momentum of sending scholars and students abroad, which is guided by government-sponsored programs and dominated by self-funded study abroad, and the main destinations are Europe and the United States. In 2017, China sent 312,000 scholars and students abroad to study in 94 countries. Visiting scholars numbered 128,000, accounting for $41.17 \%$ of the total number of dispatched learners, and graduate students numbered 132,000 , accounting for $42.29 \%$. The number of publicly funded overseas students doubled from the previous year, reaching 359,000, an increase of $119.71 \%$. In 2017, 541,300 students studied abroad at their own expense, accounting for $88.97 \%$ of the total number of students studying abroad ${ }^{2}$. According to the 2018 White Paper on Chinese Studies published by the New Oriental, the United States was still the most important destination of academic visits for four consecutive years, and nearly half of the visiting students prefer the United States. However, due to the uncertain political concerns between China and the United States and the impact of bilateral trade wars, the proportion is steadily declining year by year. The willingness of Chinese students to study in the United States has dropped from $49 \%$ of 2017 to $44 \%$ of 2018. By comparing the data of the New Oriental for the four consecutive years, we may find that the proportion of visiting European and Asian countries were rising, such as Germany, France, Hong Kong, Japan, and Singapore. An important reason for the "cooling down" of studying in the United States is that applicants were concerned about the safety of foreign students and the Trump administration's policy towards foreign students ${ }^{3}$.

\section{The Coming Trouble of the Chinese Visiting Scholars and Students in the US?}

As of 2016, there were over 34,000 Chinese students in American institutes and universities, and many others coming for summer camps and in "Bridge" programs, as more Chinese parents are sending their children to American colleges and universities ${ }^{4}$. And recruitment for high-performing Chinese scholars and students continues to be important business of the American institutes and universities to improve their ranking, reputation, and internationalization.

In 2016, 2017, and 2018, the number of international students in the United States surpassed one million for three consecutive years, ranking the first in the world, which increased by roughly $1.5 \%$ to reach a new high

\footnotetext{
2 The dual growths of Chinese scholars and students in studying abroad and returning home. Retrieved from http://www.moe.gov.cn/jyb_xwfb/gzdt_gzdt/s5987/201803/t20180329_331771.html.

3 The new oriental issues the 2018 Chinese Studying Abroad White Paper and Chinese students studying in America have declined. Retrieved from http://baijiahao.baidu.com/s?id=1601226712115492321\&wfr=spider\&for=pc.

${ }^{4}$ China's role in international education by the number. The Huffington Post, November 14, 2016. 11/14/2016 12:04 am ET.
} 
of 1,094,792. The research report of Open Doors 2018, released by the Institute of International Education (IIE) and the U.S. Department of State's Bureau of Educational and Cultural Affairs (ECA), highlighted the impact of international education on the US higher education sector. It highlighted that international students made a significant financial impact on the United States in 2017, contributing \$42.4 billion to the US economy through tuition, room, and board, and other expenses, according to the U.S. Department of Commerce. "International students studying alongside Americans are a tremendous asset to the United States”, said Marie Royce, Assistant Secretary of State for Educational and Cultural Affairs (Institute of International Education, 2018).

We need to develop leaders in all fields who can take on our toughest challenges. We need people who can find solutions that keep us secure and make us more prosperous. We want to send a message that international education makes us stronger as a country.

However, the rhetoric that the Trump administration applied indicates that US-China competition, if not a "Cold War", is inevitable. According to the State Department, the US government has shortened the visa period for some Chinese citizens since June 11, 2018. Under the new policy, US consular officials may limit the validity of visas rather than take the usual practice of issuing visas for the longest period. According to the instructions given to the US embassy and consulate, if Chinese graduate students study in certain fields, such as robotics, aviation, and high-tech manufacturing, the visa time limit will be limited to one year, because China places these areas as the focus of its future of manufacturing, i.e., the "Made in China 2025" plan, an American official said ${ }^{5}$. The US may want to slow down China's ambitious plan to rival with the US in high-tech arena.

On October 4, 2018, Vice President Mike Pence addressed the Hudson Institute on the Trump Administration's policy toward China, discrediting Chinese visiting scholars to the United States, which is described by Chinese and American scholars as the "New Cold War Declaration” of the United States towards China in the new era. Pence stressed that ${ }^{6}$,

... But the media is not the only place where the Chinese Communist Party seeks to foster a culture of censorship. The same is true across academia. I mean, look no further than the Chinese Students and Scholars Association, of which there are more than 150 branches across America's campuses. These groups help organize social events for some of the more than 430,000 Chinese nationals studying in the United States. They also alert Chinese consulates and embassies when Chinese students, and American schools, stray from the Communist Party line.

According to Pence's assumption, Chinese visiting scholars and students, together with Confucius Institutes are under rhetoric attacks by the US, which are perceived as the tool of China's "sharp power". The Trump administration stressed that Chinese authorities portray the Confucius Institutes as being similar to France's Alliance Française or Germany's Goethe-Institute, both of which receive government funding to give language and culture classes. Yet, unlike those freestanding organizations, the Confucius Institutes are embedded within educational institutions. Little about these institutes is transparent. It is hard to say, for instance, what amount of Chinese government money goes to individual host universities. Chinese embassies and consular officials have been detected channeling resources and programmatic guidance to associations of Chinese students in ways that suggest inappropriate behavior and plans to manipulate the academic environment (Christopher, 2018).

\footnotetext{
${ }^{5}$ According to the foreign media, the US would shorten visas of Chinese students and Chinese government responded. Retrieved May 31, 2018, from http://www.cankaoxiaoxi.com/world/20180531/2275741.shtml.

6 Remarks by vice President Pence on the administration's policy toward China. Retrieved October 4, 2018, from https://www.voachinese.com/a/pence-speech-20181004/4600329.html.
} 
In October 2018, China's flagship science talent recruitment programme, the Thousand Talents Plan, has gone underground amidst intensifying scrutiny by United States government agencies for China's suspected role in the theft of US technologies and intellectual property. A climate of fear has engulfed Chinese scientists in both countries worried that association with the previously prestigious programme will make them targets of US investigations, including by the Federal Bureau of Investigation (FBI) (Nature, 2018).

In early 2019, the US Senate's Committee on Homeland Security and Governmental Affairs issued a staff report titled “China’s Impact on the U.S. Education System”, which argues that (Rob \& Tom, 2019),

Confucius Institutes' soft power encourages complacency towards China's pervasive, long-term initiatives against both government critics at home and businesses and academic institutions abroad. Those long-term initiatives include it's Made in China 2025 Plan, a push to lead the world in certain advanced technology manufacturing. The Thousand Talents program is another state-run initiative designed to recruit Chinese researchers in the United States to return to China for significant financial gain—bringing with them the knowledge gained at US universities and companies.

Therefore, the Trump administration is upset with the huge number of Chinese visiting scholars and students charging them as the political tools of Beijing for commercial espionage, political infiltration, and security penetration, the extension of "China Threat" and "Sinophobia".

\section{Conclusions}

China is the largest developing country and the US is the largest developed country. The treatment and scale of Chinese scholars and students in the United States are greatly shaped by the Sino-US political relations, which has become a barometer of the political relations between the two sides. As of 2018, nearly one-third of the more than one million foreign students attending American schools came from China, twice the number of foreign students. Chinese students account for about $10 \%$ of all doctoral degree holders in the United States, mostly in science and engineering. About 80\% of Chinese Ph.D. holders continue to work in the United States after receiving their degrees. Many Chinese engineers work in American technology companies and artificial intelligence. According to statistics, Chinese students spend at least $\$ 12$ billion a year on tuition and living expenses, which provide thousands of jobs on and off American universities, and become an important "ballast stone” for the development of Sino-US relations (Shanghai Observation, 2019).

However, since the establishment of diplomatic relations between China and the United States, the flow of Chinese visiting scholars and students have been disturbed by political factors, and thus, become barometers of Sino-American political relations. From 1978 to 1988, China and the United States were in a "honeymoon relationship". Chinese visiting scholars and students were welcomed by the US government. These visiting scholars and students received better treatment than the Soviet visiting scholars and students due to the two communist states' divergent political ties with the US. From 1989 to 2012, China and the United States had “cautious engagement” with China. The United States both engaged and contained China. Although Chinese scholars and students studying in the United States often encountered resistance, they were still on a healthy track. Since 2013, with China's diplomacy becoming more proactive, and with the decline of the US comprehensive power, the United States has begun to limit, monitor, and even prohibit some of Chinese visiting scholars and students. Especially with the increase of Sino-US trade war, the disputes over South China Sea issue, discords on security, and other frictions, Trump government began to regard visiting scholars, students, and Confucius Institute as part of China's sharp power. Nearly 400,000 visiting scholars and students in the United States have been "sandwiched" by China-US strategic competition. In short, the flow of Chinese 
visiting scholars and students to the United States are subordinate to Sino-American political relations, and they will probably face more severe hurdles of the upcoming "New Cold War" between China and the United States.

\section{References}

Center on Religion and Chinese Society Purdue University. (2018, October 17). 2018 Purdue survey of Chinese students and scholars in the United States: A general report (p. 4). Indiana: West Lafayette.

Christopher, W. (2018). What is sharp power? Journal of Democracy, 29(3), 13-14.

Ding, L., \& Li, H. Z. (2012). Social networks ad study abroad: The case of Chinese visiting students in the US. China Economic Review, (23), 581-582.

Institute of International Education. (2018). Number of international students in the United States reaches new high of 1.09 million. Retrieved February 5, 2019, from https://www.iie.org/Why-IIE/Announcements/2018/11/2018-11-13-Number-ofInternational-Students-Reaches-New-High

John, W. (1984, June 1). China-U.S. science cooperation blooming. Science, 224(4652), 967.

Li, M. J. (2017). Sino-US cultural exchange: Today’s dedication is for tomorrow’s achievement. Beijing Weekly, October 10, 2017.

Mo, X., Xia, C., \& Aaron, M. K. (2015). Chinese visiting scholars’ academic socialization in US institutions of higher education: A qualitative study. Asia Pacific Journal of Education, 35(2), 290-291.

National Academy of Sciences. (1988). Chinese students in America: Policies, issues, and numbers (pp. 81-88). Washington, DC: The National Academies Press.

Nature. (2018). China hides identities of top scientific recruits amidst growing US scrutiny. Retrieved October 24, 2018, from https://www.nature.com/articles/d41586-018-07167-6

Niu, W. X. (2019). Studying abroad. China's Economy Weekly, October 22, p. 43.

Xi, J. P. (2013). Remarks on the 100 Anniversary of Overseas-Educated Scholars Association of China. Retrieved October 21, 2013, from http://www.wrsa.net/content_39103656.htm

Xinhua Net. (2017). China, U.S. conclude social, people-to-people talks with substantial results. Retrieved July 25, 2019, from http://www.xinhuanet.com//english/2017-09/29/c_136649377.htm

Yue, T. T. (2018). Forty years of Chinese visiting scholars and students in the US and education development: A review. Journal of Jiangxi Science and Technology University, (2), 103-109.

Rob, P., \& Tom, C. (2019, January). China's impact on the U.S. education system (p. 1). United States Senate, Committee on Homeland Security and Governmental Affairs, Staff Report.

Shanghai Observation. (2019). The US aims to shorten Chinese visiting students' visa and what should they pay attention to? Retrieved August 11, 2019, from https://www.shobserver.com/news/detail?id=91369. 